\title{
Satellite Based Estimation and Validation of Rainfall Distribution in Monsoon over Washim (Maharashtra), India
}

\author{
Sudarshan Awatade $^{1^{*}}$, Sumedh R. Kashiwar ${ }^{2}$, Souvik Ghosh ${ }^{1}$, R.B. Singhandhupe ${ }^{3}$, \\ Usha R. Dongarwar ${ }^{4}$ and Digvijay S. Dhakre ${ }^{5}$
}

${ }^{1}$ Department of Agricultural Extension, ${ }^{2}$ Department of Soil Science and Agricultural

Chemistry, ${ }^{5}$ Department of Agricultural Economic \& Agricultural Statistics, Palli Shiksha Bhavana (Institute of Agriculture), Visva-Bharati, Sriniketan, West-Bengal-731236, India

${ }^{3}$ Department of Agronomy, Central Institute for Cotton Research, Nagpur, Maharashtra-441108, India

${ }^{4}$ Krishi Vigyan Kendra, Sakoli, Bhandara, Maharashtra-441802, India

*Corresponding author

\section{Keywords}

Rainfall, TRMM,

Vidharbha

Article Info

Accepted:

10 July 2018

Available Online:

10 August 2018

\section{A B S T R A C T}

Worldwide agriculture is sensitive to short-term changes in weather and to seasonal, annual and longer-term variations in climate. The variations in the meteorological parameters have overriding influence on the agricultural systems. It is widely believed that developing countries such as India will be impacted more severely than developed countries, where, about $56 \%$ of the net cultivated area is rain-fed that largely depends on monsoon rainfall. Thus accurate estimation of rainfall is crucial for crop yield assessment, water resource management and flood and drought monitoring for the area. But, traditional precipitation records are thought to be rarely complete, to analyze these limitations a comparison between rain gauge observations and satellitebased estimates such as the Tropical Rainfall Measuring Mission (TRMM) is carried out in this paper. Different statistical tools like coefficient of determination, Mean Bias Error, Root Mean Square Error and NRMSE are used to have validation of TRMM data with rain gauge data. TRMM data found overestimated to the rain gauge data with $58.17 \%$ of error, capturing $60.6 \%$ of variability in spatial distribution with traditional rain gauges. It is concluded from the analysis that there is some dissimilarity in the spatial distribution between the two which may due to lack of ground rain gauge stations at some remote areas or diversified topography of the district area. Hence, it may be useful in estimating rainfall particularly in regions where no gauge observations available and therefore such measurements are useful for many water related applications. 


\section{Introduction}

Worldwide agriculture is sensitive to shortterm changes in weather and to seasonal, annual and longer-term variations in rainfall. It is widely believed that developing countries like India will be impacted more severely than developed countries. Where, about $56 \%$ of the net cultivated area of the country is rain-fed that largely depends on monsoon rainfall, accounting for $44 \%$ of food production contributing 17-18 percent to the country's GDP. Large parts of the country are severely affected due to deficit monsoon rainfall where Government of India spends large amount of money on providing relief in affected areas. Thus accurate estimation of rainfall is crucial for crop yield assessment, water resource management and flood and drought monitoring for the area. But our knowledge of rain in the Tropics is limited due to poor conventional observations. Rain gauges can deliver accurate point observations but have poor ability to describe the spatial structure of rainfall especially due to high rainfall variability because they are punctual instruments that cover an area of about $10^{-1} \mathrm{~m}^{2}$ (Nerini et al., 2015). In many areas, precipitation estimates are also subject to considerable uncertainty due to the small number of rain gauges or non-representative observation sites. Ultimately, recording devices, human operators, and data transmission are susceptible to errors and outages for various reasons. Hence, traditional precipitation records are rarely available with good spatial and temporal coverage (Hongfen et al., 2017). To overcome these limitations of rain gauge measurements, remote sensing techniques using space borne sensors provide an excellent complement to continuous monitoring of rain event both spatially and temporally. It is one of the most useful missions for calculating rainfall over the earth. The TRMM satellite was developed by the National Aeronautics and Space
Administration (NASA) Goddard Space Flight Center (GSFC), on November 28, 1997. It is a joint space mission between the NASA and the Japan Aerospace Exploration Agency (JAXA). In this research work TRMM 3B43 V7 is especially used for determination of the rainfall variations. It produces three hourly rainfall data at $0.25^{\circ} \times 0.25^{\circ}$ spatial resolutions estimating rainfall and energy exchange on tropical and subtropical regions of the world based on the characteristics of cloud cover, cloud tops and temperature (Shukla, et al., 2014; Huffman et al., 2007). It is the first mission dedicated for measuring tropical and subtropical rainfall (Simpson, et al., 1988 and Kummerow, et al., 2000) aimed to measure tropical and subtropical rainfall through microwave and visible infrared sensors with continuous representation of the distribution of rainfall data (Santos, 2014). In recent years, satellite rainfall estimates based on microwave data have demonstrated more promises for studies of the tropical convective systems, including the monsoon. But according to Shukla et al., (2012) TRMM satellite data is underestimated with low accuracy, though TRMM data and rain gauge data had positive correlation. A good agreement and relationship was observed on comparing the monthly TRMM satellite rainfall data with gauge rainfall data. Similar findings of Knies, et al., (2014) and Mitra et al., (2008) stated that the satellite-based precipitation estimates suffer from deficiencies in the registration of intense rainfall events. At the same time, the remote-sensing data frequently overestimate rainfall amounts observed at the ground. Hence, it was thought imperative to conduct a validation study on recorded rain gauge data with the TRMM satellite derived rainfall estimates.

\section{Materials and Methods}

Present study was carried out in the Washim district of Maharashtra, India which comprises 
six sub divisions namely Washim $\left(77.191287^{\circ} \mathrm{E} \quad 20.087518^{\circ} \mathrm{N}\right), \quad$ Karanja $\left(77.513479^{\circ} \mathrm{E} \quad 20.550669^{\circ} \mathrm{N}\right), \quad$ Mangrulpir $\left(77.346789^{\circ} \mathrm{E} \quad 20.310143^{\circ} \mathrm{N}\right), \quad$ Malegaon $\left(77.015647^{\circ} \mathrm{E} \quad 20.278819^{\circ} \mathrm{N}\right), \quad$ Manora $\left(77.545922^{\circ} \mathrm{E} \quad 20.207221^{\circ} \mathrm{N}\right)$ and Risod $\left(76.789665^{\circ} \mathrm{E} 20.029344^{\circ} \mathrm{N}\right)$. The district is basically agriculture oriented with varied topographical and climatological features, categorized under two agro climatic zone type viz. Assured rainfall zone (ACZ-7) and Moderate Rainfall Zone (ACZ-8). Monthly rainfall data of above mentioned six rain gauge stations of Washim district (Table 1) from 2007-2017 were taken from the Indian meteorological department (IMD), Pune, India. Further seasonal rainfall data for monsoon season was calculated as more than $80 \%$ of annual rainfall is received during the monsoon season Jun-Sept and the analysis of this study compares the seasonal rainfall estimates of the TRMM data with rain gauge rainfall. The considered data sets known as 3B43 that routinely produced by the tropical rainfall measuring mission (TRMM) from passive microwave and infrared recordings.

The data are made available at no charge by the TRMM mission. This product is an optimal combination of various high quality microwave estimates to adjust infrared estimates from high-frequency geostationary observations (http://trmm.gsfc.nasa.gov/). The TRMM rainfall data is valuable in finding the rain location and intensity of rainfall. The comparison of observed rainfall and TRMM rainfall was not done station by station data but monthly and average seasonal rainfall over the entire district region on sub-divisional scale. It was found that the inverse squared distance method in GIS software gave better results compared to the other interpolation methods. In this method, the weighted rainfall is calculated from the rain gauge data by its distances from the interpolating point. This helps in improving the accuracy of the spatial interpolation in regions having low density of rain gauge networks. To validate the satellite rainfall estimates with the rain gauge rainfall observations following statistical measures were used:

Coefficient of determination $\left(\mathrm{R}_{2}\right)$ : It is the degree of linear association between the observed rainfall and satellite estimated rainfall. The goodness of fit of the relation is evaluated by $\mathrm{R}_{2}$ (Eq.1)

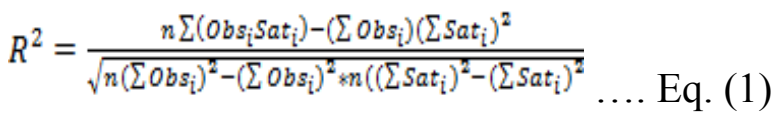

Where $\mathrm{R}^{2}$ is the coefficient of determination, where, $\mathrm{Obs}_{i}$ the observed rainfall measurements, $\mathrm{Sat}_{i}$ stands for satellite rainfall estimates, and $\mathrm{n}$ the number of data pairs.

Mean Bias Error (MBE): It is the simple ratio of average satellite rainfall estimation to average observed rainfall estimation values (Eq.2). A bias of 1.1 means the satellite rainfall is $10 \%$ higher than the average

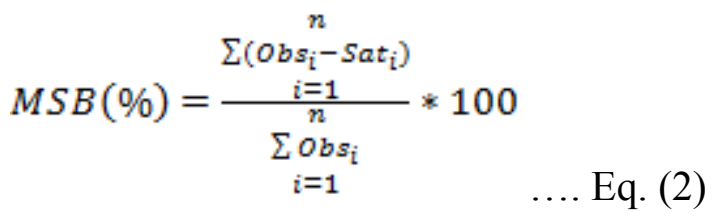

Root Mean Square Error (RMSE): measures are used to assess the difference between the distributions of the rain gauge observed rainfall with satellite rainfall estimation. It calculates a weighted average error, with reference to the square of the error. RMSE is useful when large errors are undesirable. The lower the RMSE score, the closer the satellite rainfall estimation represents the observed ground rainfall measurement (Eq.3).

RMSE $=\sqrt{\frac{\sum\left(O b s_{i}-S a t_{i}\right)^{2}}{i=1}}{ }^{n} \quad \ldots$. Eq. (3) 
Where RMSE is the root mean square error, $O b s_{i}$ the observed rainfall measurements, $\mathrm{Sat}_{i}$ the satellite rainfall estimates, and $\mathrm{n}$ the number of data pairs. RMSE is an inappropriate measure for calculating mean error and can be easily misinterpreted (Willmott et al., 2005) in this study, NRMSE (Eq.4) is also used to evaluate the accuracy of TRMM precipitation.

$\operatorname{NRMSE}(\%)=\operatorname{RMSE} /\left[\begin{array}{c}n \\ \sum O b s_{i} \\ i=1 \\ n\end{array}\right] * 100$

The NRMSE, is considered to be excellent if it is $<10 \%$, good if $10-20 \%$, fair if $20-30 \%$, and poor $>30 \%$ (Jamieson, et al., 1991 and Signoretto, et al., 2011). Pearson product moment correlation (Sample Correlation Coefficient):

$r=\frac{\sum(x-\bar{x})(y-\bar{y})}{\sqrt{\Sigma(x-\bar{x})^{2}} \sqrt{\Sigma(y-\bar{y})^{2}}} \ldots$. Eq. (5)

The correlation should be between +1 to -1 showing perfect increasing or decreasing linear relationship and the values in between shows the degree of linear relationship between estimated and observed values. If $r$ is 0 that means there is no linear relationship between the variables.

\section{Results and Discussion}

India's most of the rainfall (more than $80 \%$ ) is received during the monsoon season (JunSept), so, the analysis compares the seasonal rainfall estimates of the TRMM data products with that of rain gauge rainfall data over the Washim district region during 2007-2017.

\section{Seasonal performance over the district}

The statistics of average monthly rainfall during monsoon season (Jun-Sept) recorded at
TRMM 3B43 and rain gauge for the six stations of Washim district region are given in (Table 1, Table 2) along with the annual rainfall for comparison. It is found that monthly average seasonal rainfall data of rain gauge at Washim station have overestimated by TRMM 3B43 with low difference for the year 2009, 2013, 2014 and 2017 as well as at Malegaon for 2013 and 2017 and Mangrulpir, Manora and Karanja during 2017, 2013 and 2017 respectively. Whereas only for the year 2013 Mangrulpir station rain gauge data have underestimated by TRMM 3B43 with low difference. In Figure 2 the TRMM values are found to the higher side for most of the monsoon months (Jun-Sept) of year 2007, 2008, 2009, 2010, 2011, 2012, 2014, 2015 and 2016 except for the year 2013 and 2017 where have hardly any difference between the two. It is cleared from Table 1,2 and Figure 2 that observed average monthly rainfall readings for monsoon season in rain gauge and TRMM 3B43 are low comparable.

Table 3 summarizes the bias, MSB \%, MAE, RMSE and NRMSE between the monthly rain gauge observations and TRMM data sets for monsoon season (2007-2017). The 11-year monthly averages of monsoon season in the rain gauge and TRMM dataset are 183.17 and 289.71 respectively. The big difference between rain gauge and TRMM is observed. The estimates of TRMM (3B43) algorithm tend to be higher than rain gauge observations, the biases are also much high with error of $58.17 \%$. On the other hand the maximum average monthly rainfall in monsoon season in case of observed rainfall is $306.5 \mathrm{~mm}$ in the year 2013 and in TRMM rainfall is $371.2 \mathrm{~mm}$ in the year 2010. The level of confidence at 95\% was 36.60 in Rain gauge and 38.08 in TRMM (Table 3). The TRMM 3B43 data (0.41 ) is found to be moderately skewed with lack of outliers whereas rain gauge observation (1.28) data as highly skewed with heavy tails or outliers. 
Table.1 Seasonal rainfall observed in Rain gauge and TRMM data sets of Washim District (2007-2017)

\begin{tabular}{|c|c|c|c|c|c|c|c|c|c|c|c|c|c|c|c|}
\hline \multirow[t]{2}{*}{ Station } & \multirow[t]{2}{*}{ Long. } & \multirow[t]{2}{*}{ Lat. } & \multirow[t]{2}{*}{ Annual } & \multicolumn{2}{|c|}{2007} & \multicolumn{2}{|c|}{2008} & \multicolumn{2}{|c|}{2009} & \multicolumn{2}{|c|}{2010} & \multicolumn{2}{|c|}{2011} & \multicolumn{2}{|c|}{2012} \\
\hline & & & & $\mathrm{R} / \mathrm{G}$ & TRMM & $\mathrm{R} / \mathrm{G}$ & TRMM & $\mathrm{R} / \mathrm{G}$ & TRMM & $\mathrm{R} / \mathrm{G}$ & TRMM & $\mathrm{R} / \mathrm{G}$ & TRMM & $\mathrm{R} / \mathrm{G}$ & TRMM \\
\hline Washim & 77.191287 & 20.087518 & 871.40 & 212.50 & 359.96 & 169.73 & 331.23 & 153.05 & 203.18 & 265.13 & 377.09 & 178.43 & 288.21 & 178.43 & 313.23 \\
\hline Risod & 76.789665 & 20.029344 & 769.61 & 215.25 & 373.73 & 181.75 & 306.33 & 131.00 & 229.56 & 240.08 & 367.81 & 151.95 & 298.34 & 151.95 & 315.34 \\
\hline Malegaon & 77.015647 & 20.278819 & 783.18 & 191.75 & 331.19 & 158.75 & 264.95 & 131.50 & 245.40 & 264.83 & 368.06 & 150.00 & 284.60 & 150.00 & 272.89 \\
\hline Mangrulpir & 77.346789 & 20.310143 & 820.04 & 206.10 & 335.32 & 127.33 & 258.30 & 122.95 & 204.59 & 249.80 & 385.10 & 187.63 & 288.87 & 187.63 & 300.36 \\
\hline Manora & 77.545922 & 20.207221 & 737.05 & 181.05 & 336.05 & 116.40 & 298.17 & 87.40 & 229.51 & 266.60 & 347.09 & 203.20 & 373.13 & 203.20 & 362.84 \\
\hline Karanja & 77.513479 & 20.550669 & 742.18 & 237.40 & 360.40 & 101.68 & 303.92 & 150.00 & 211.26 & 182.68 & 381.97 & 190.23 & 319.12 & 190.23 & 311.80 \\
\hline
\end{tabular}

R/G: Rain Gauge Station, TRMM: Tropical Rainfall Measurement Mission

Table.2 Seasonal rainfall observed in Rain gauge and TRMM data sets of Washim District (2007-2017)

\begin{tabular}{|c|c|c|c|c|c|c|c|c|c|c|c|c|c|}
\hline \multirow{2}{*}{ Station } & Long. & Lat. & Annual & \multicolumn{2}{|c|}{2013} & \multicolumn{2}{|c|}{2014} & \multicolumn{2}{|c|}{2015} & 2016 \\
\hline & & & & R/G & TRMM & R/G & TRMM & R/G & TRMM & R/G & TRMM & R/G & TRMM \\
\hline Washim & 77.191287 & 20.087518 & 871.40 & 339.00 & 367.24 & 209.20 & 239.68 & 162.23 & 248.07 & 245.80 & 313.30 & 148.33 & 184.71 \\
\hline Risod & 76.789665 & 20.029344 & 769.61 & 271.38 & 340.29 & 149.13 & 252.69 & 159.78 & 257.90 & 181.60 & 292.21 & 157.40 & 232.40 \\
\hline Malegaon & 77.015647 & 20.278819 & 783.18 & 299.38 & 327.59 & 149.10 & 222.86 & 137.53 & 220.58 & 186.83 & 289.35 & 156.95 & 184.50 \\
\hline Mangrulpir & 77.346789 & 20.310143 & 820.04 & 380.10 & 333.44 & 108.27 & 214.56 & 150.80 & 237.87 & 207.43 & 300.09 & 130.10 & 173.99 \\
\hline Manora & 77.545922 & 20.207221 & 737.05 & 320.63 & 342.74 & 118.93 & 267.39 & 122.47 & 270.56 & 192.68 & 321.44 & 99.23 & 181.07 \\
\hline Karanja & 77.513479 & 20.550669 & 742.18 & 228.40 & 320.97 & 109.05 & 268.52 & 144.10 & 286.34 & 203.58 & 315.10 & 116.43 & 174.84 \\
\hline R/G: Rain Gauge Station, TRMM: Tropical Rainfall Measurement Mission & & & & & \\
\hline
\end{tabular}


Table.3 Statistical analysis of average monthly rainfall recorded at Rain gauge and TRMM data set for monsoon season (Jun-Sept) during 2007-2017.

\begin{tabular}{|l|c|l|c|}
\hline \multicolumn{1}{|c}{ TRMM } & & \multicolumn{2}{c}{ Rain gauge } \\
\hline Mean & 289.7145 & Mean & 183.1694 \\
\hline Standard Error & 17.09138 & Standard Error & 16.42797 \\
\hline Median & 305.2468 & Median & 176.9042 \\
\hline Standard Deviation & 56.6857 & Standard Deviation & 54.48541 \\
\hline Sample Variance & 3213.269 & Sample Variance & 2968.659 \\
\hline Kurtosis & -0.67904 & Kurtosis & 1.380175 \\
\hline Skewness & -0.41021 & Skewness & 1.278854 \\
\hline Range & 182.6002 & Range & 177.1625 \\
\hline Minimum & 188.5857 & Minimum & 129.3167 \\
\hline Maximum & 371.1859 & Maximum & 306.4792 \\
\hline Sum & 3186.86 & Sum & 2014.863 \\
\hline Count & 11 & Count & 11 \\
\hline Confidence Level (95.0\%) & 38.08197 & Confidence Level (95.0\%) & 36.60379 \\
\hline MAE & 106.55 & & \\
\hline RMSE & 112.25 & & \\
\hline NRMSE & 0.61 & & \\
\hline MAPE & 0.63 & & \\
\hline MSB \% & 58.17 & & \\
\hline
\end{tabular}

Fig.1 Study area location map Washim District (Maharashtra)
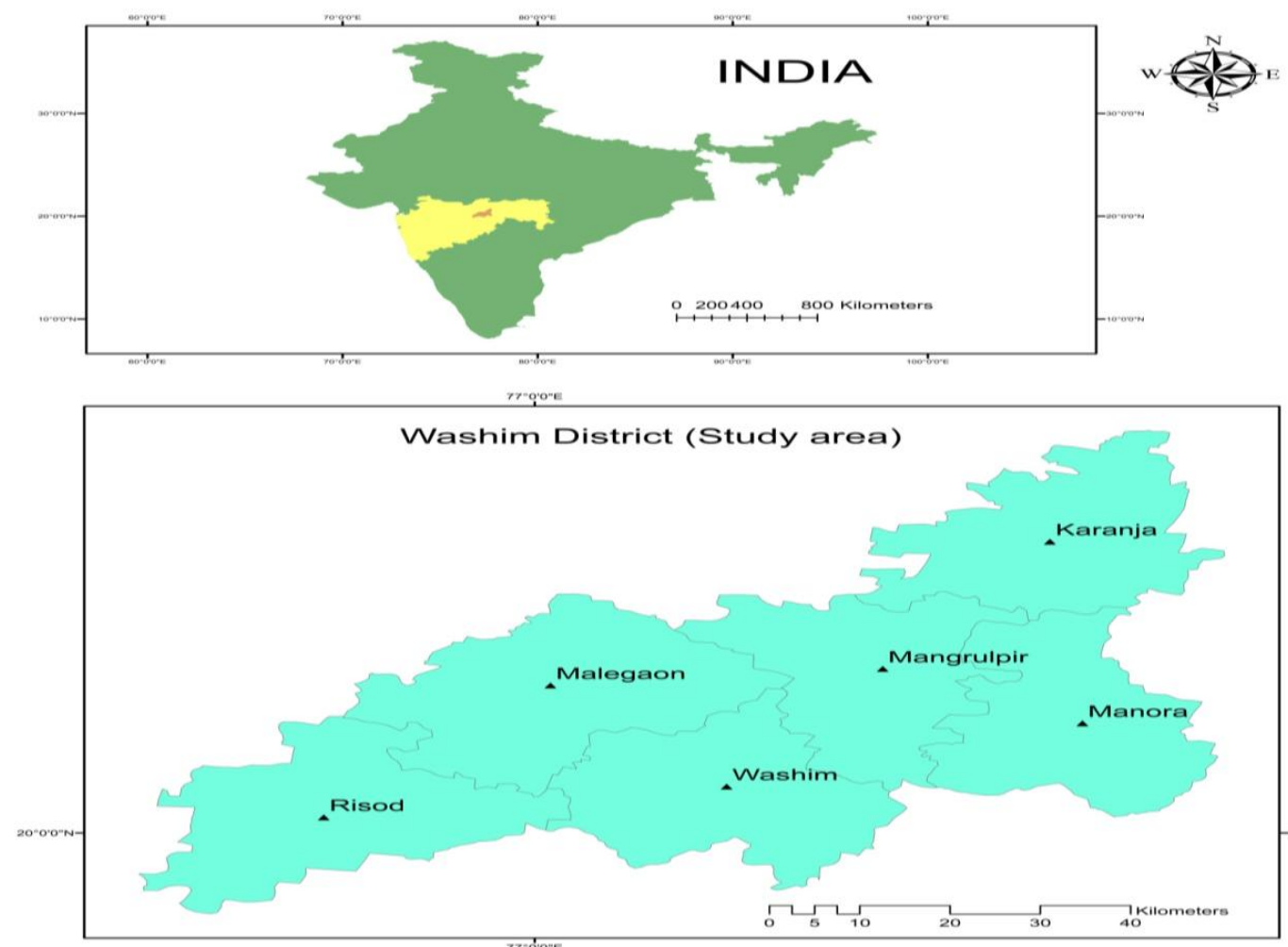
Fig.2 Time series of average monthly rain rate in Monsoon season over entire Washim District for Rain gauge and TRMM 3B43 DATA SETS

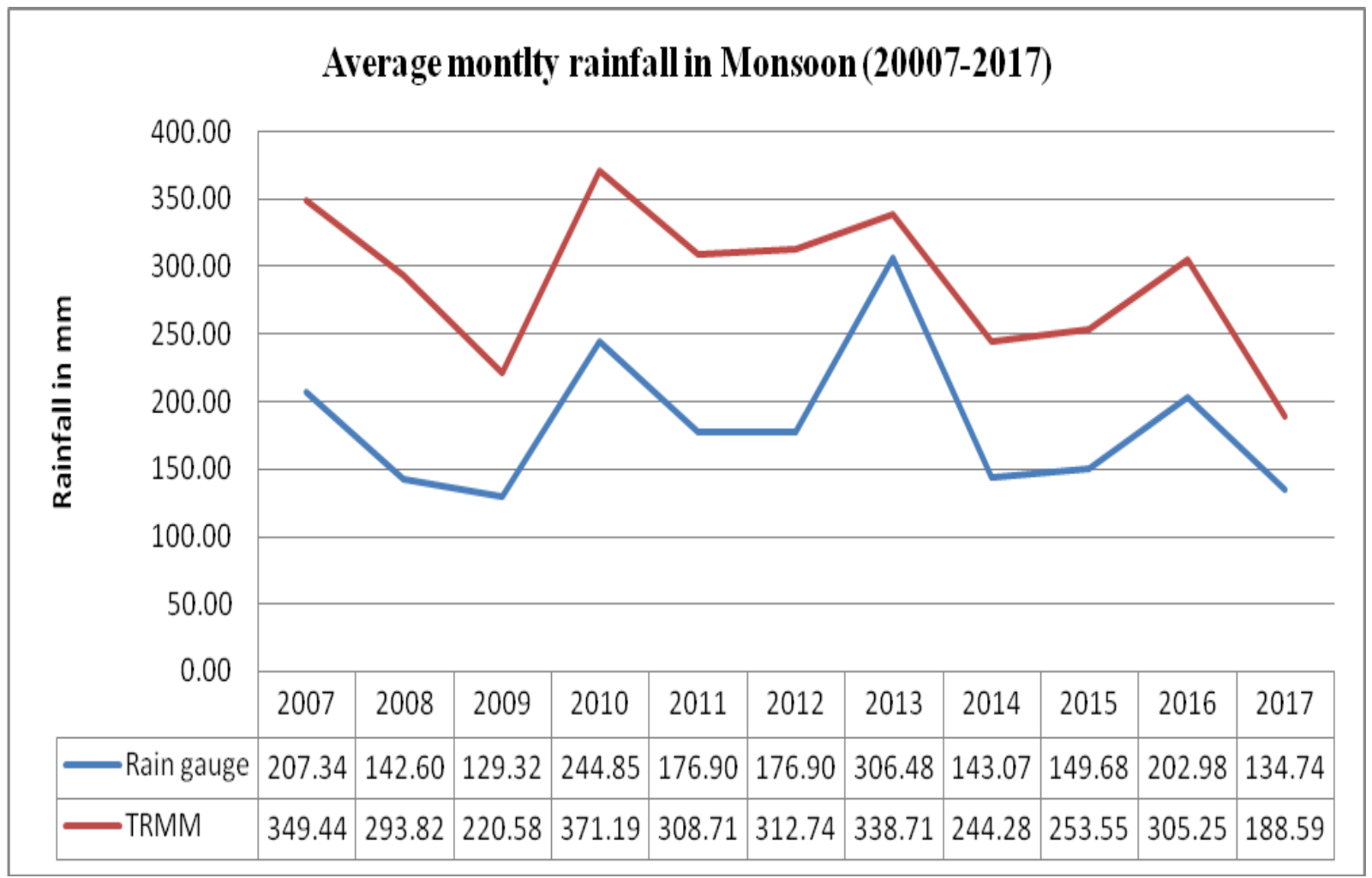

Fig.3 Scatter plot of average monthly rainfall for monsoon season (2007-2017) observed in rain gauge station and TRMM rainfall data $(\mathrm{mm})$

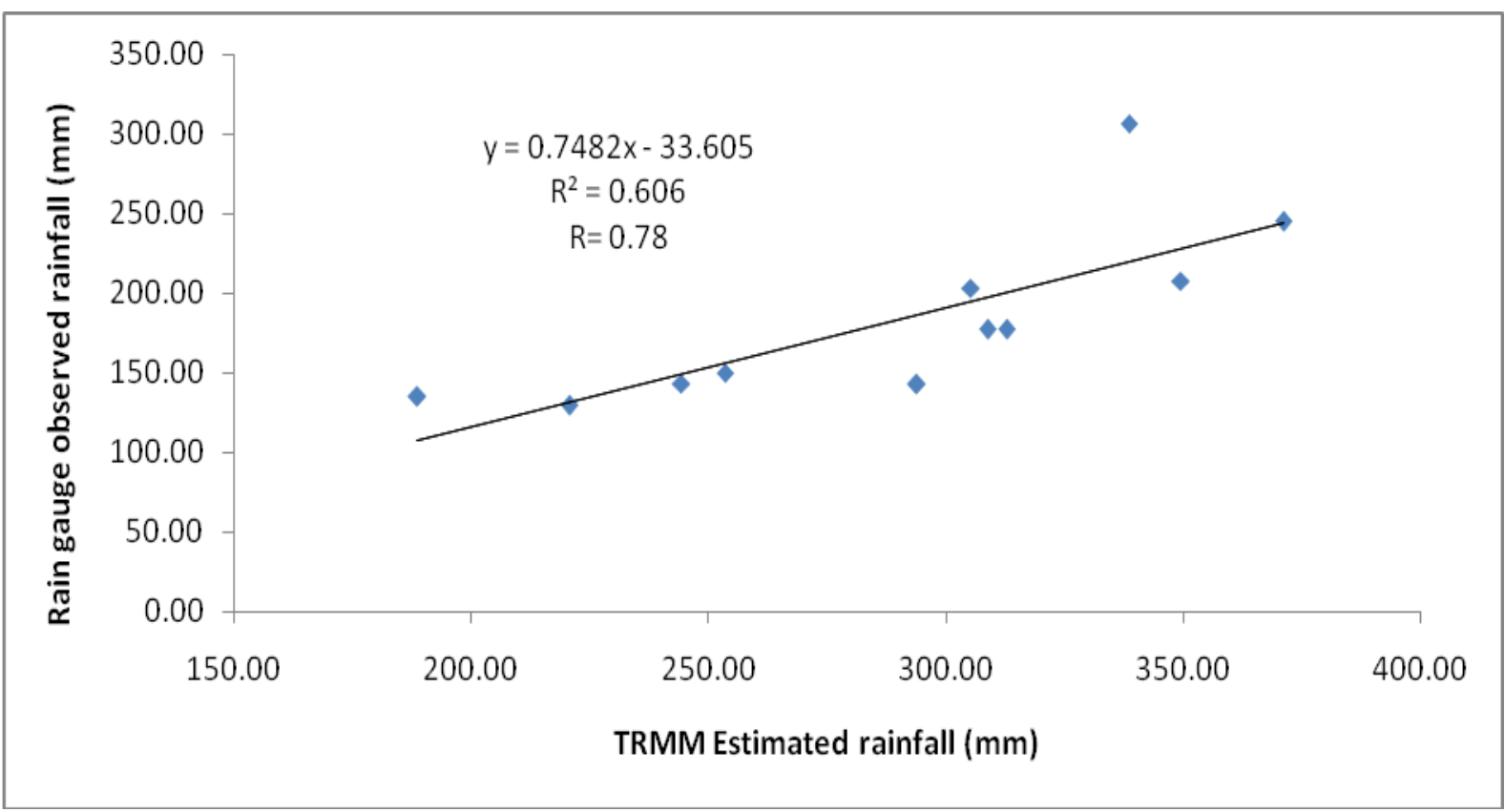




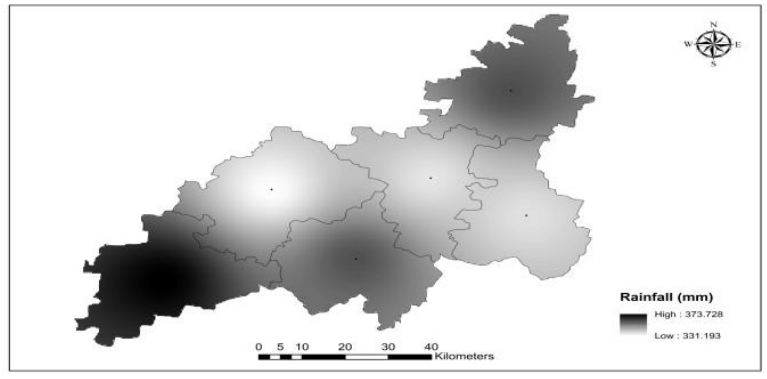

Fig.4 TRMM (2007)

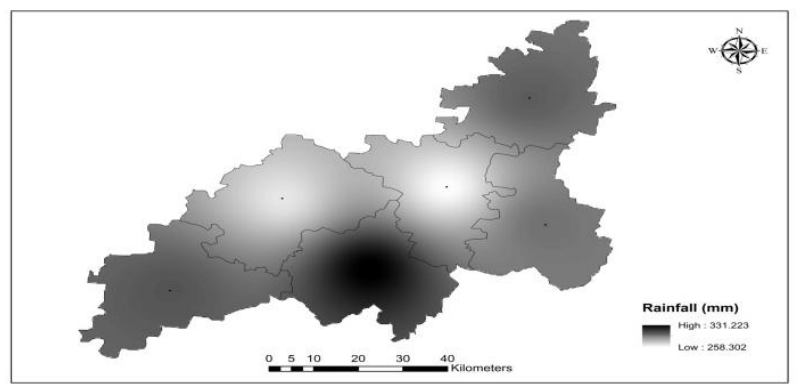

Fig.6 TRMM (2008)

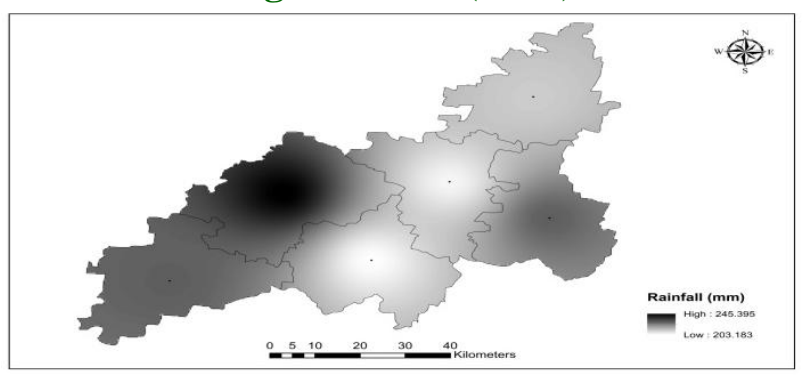

Fig.8 TRMM (2009)

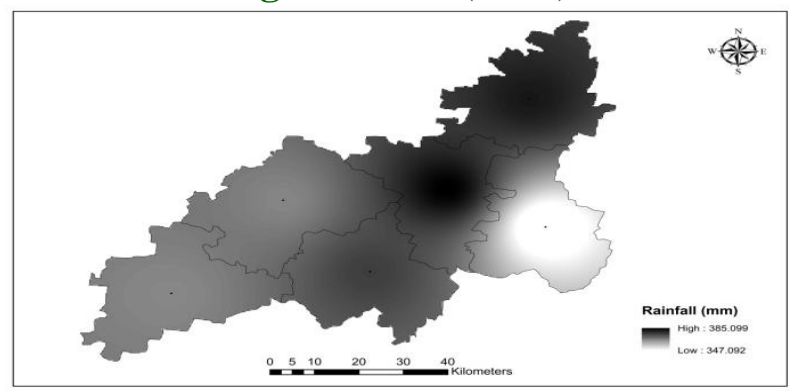

Fig.10 TRMM (2010)

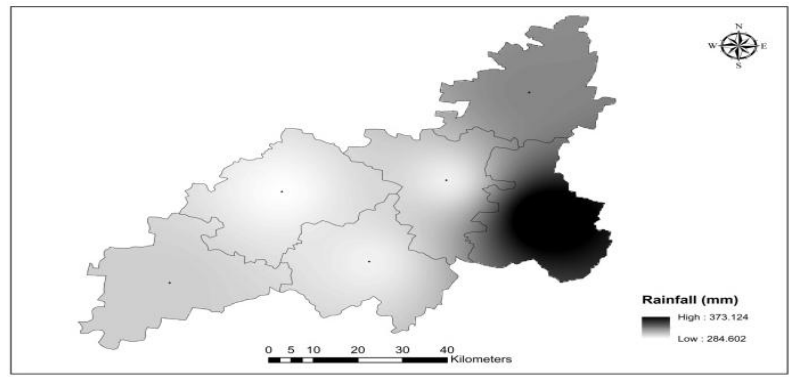

Fig.12 TRMM (2011)

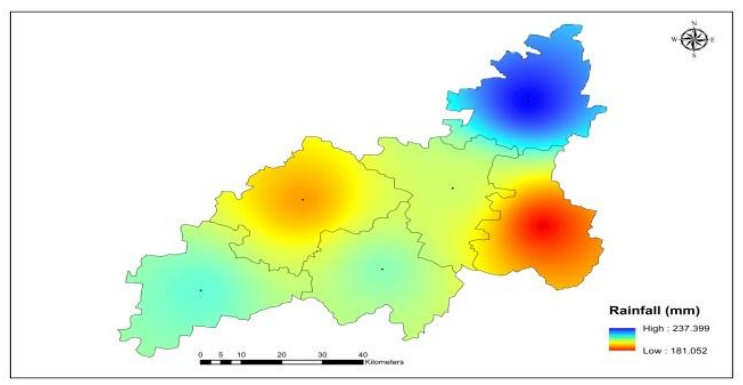

Fig.5 RGS (2007)

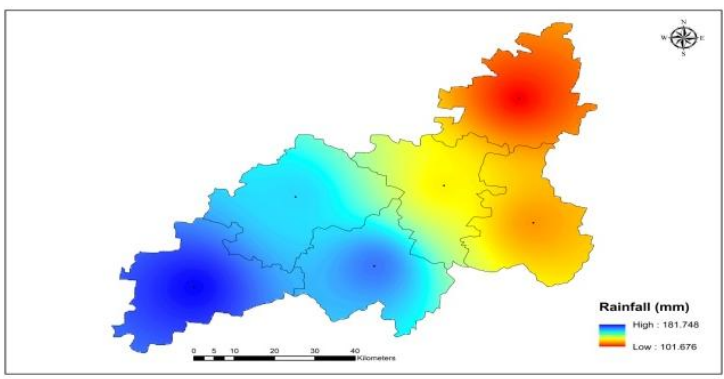

Fig.7 RGS (2008)

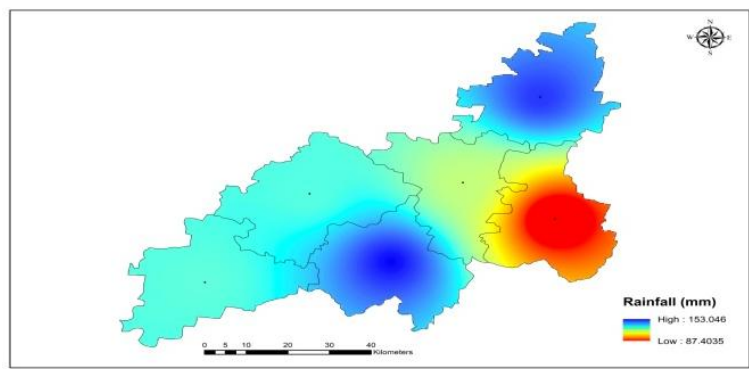

Fig.9 RGS (2009)

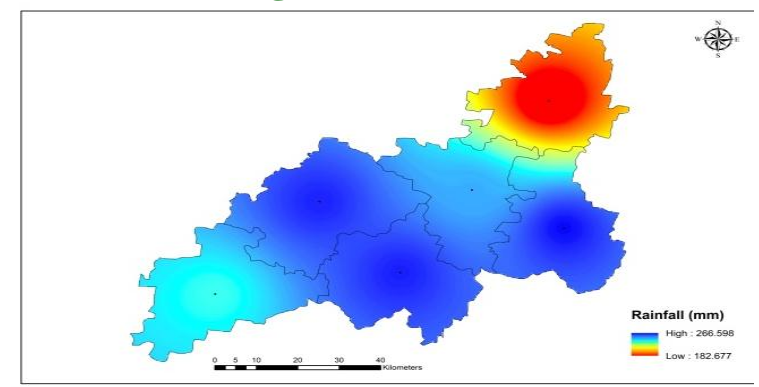

Fig.11 RGS (2010)

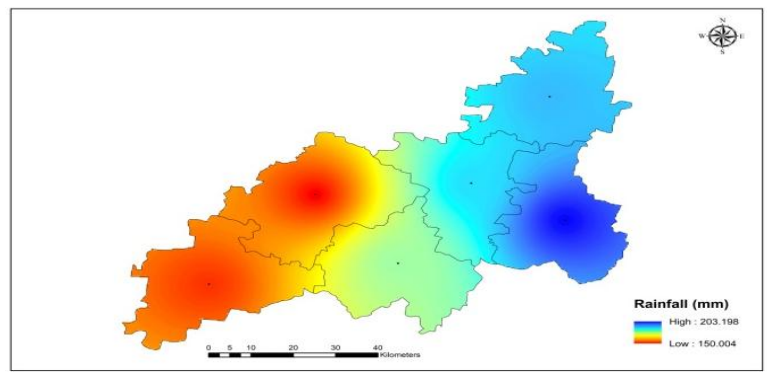

Fig.13 RGS (2011) 


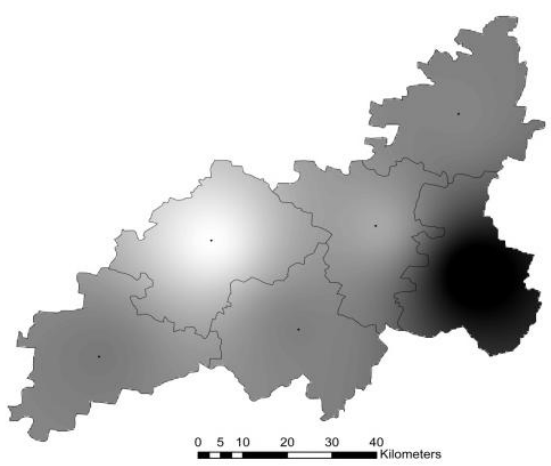

Fig.14 TRMM (2012)

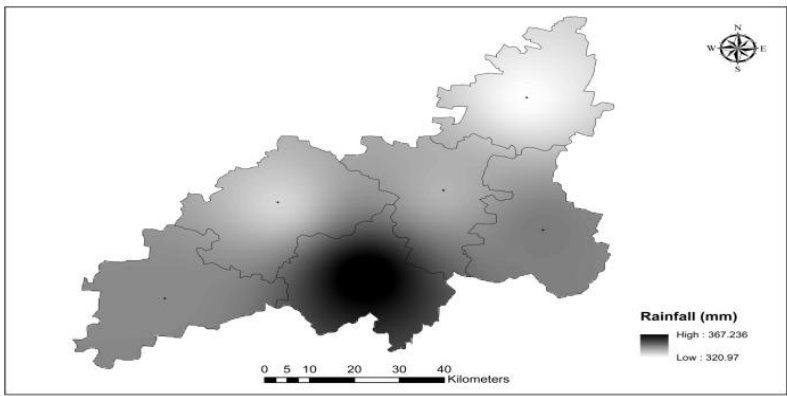

Fig.16 TRMM (2013)

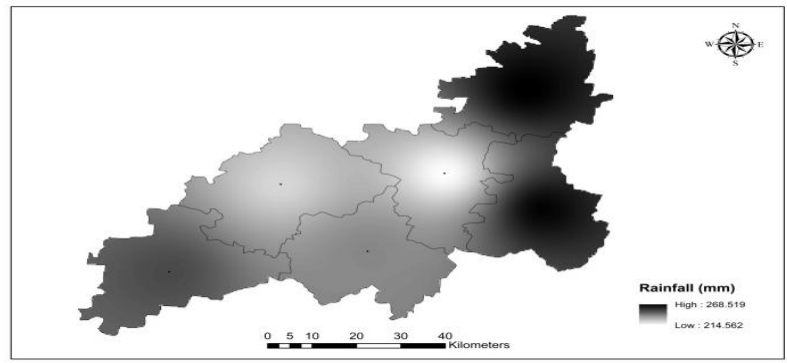

Fig.18 TRMM (2014)

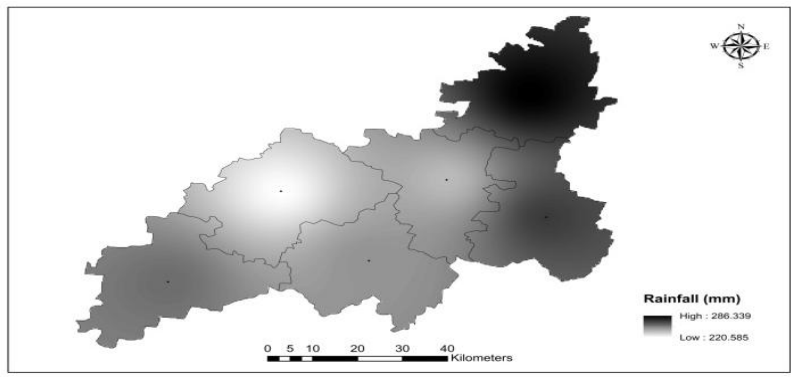

Fig.20 TRMM (2015)

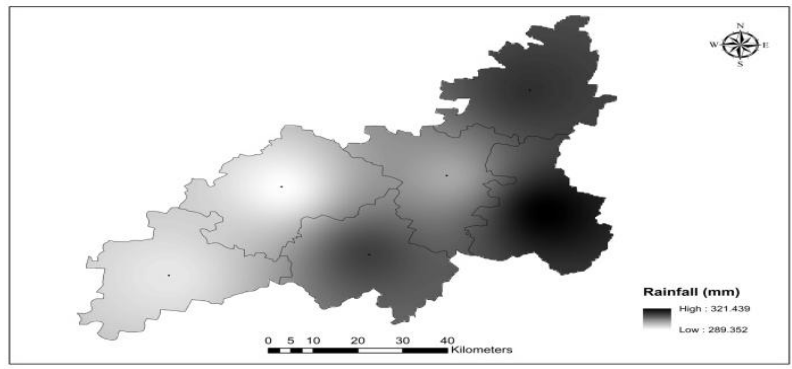

Fig.22 TRMM (2016)

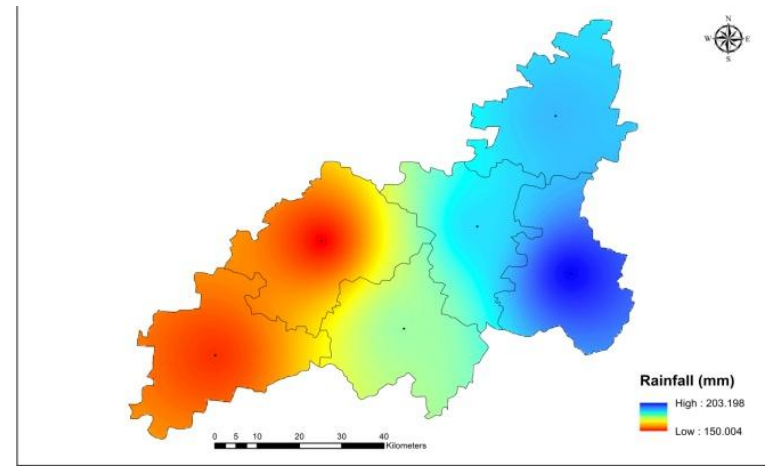

Fig.15 RGS (2012)

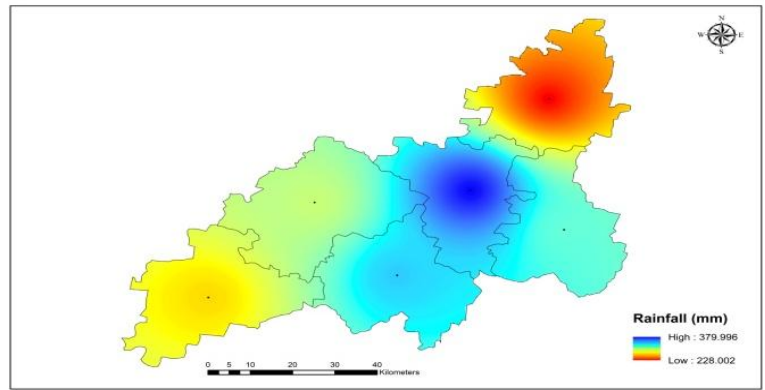

Fig.17 RGS (2013)

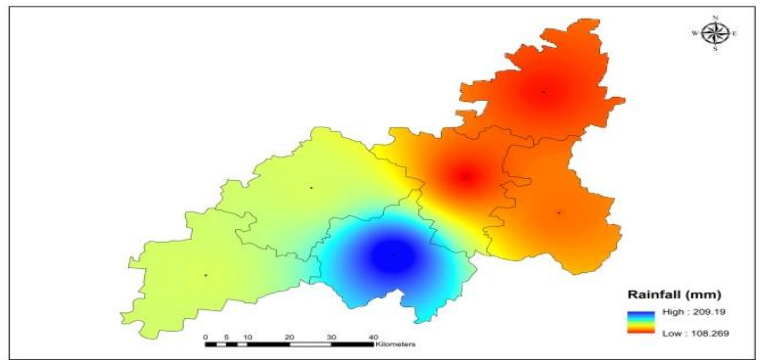

Fig.19 RGS (2014)

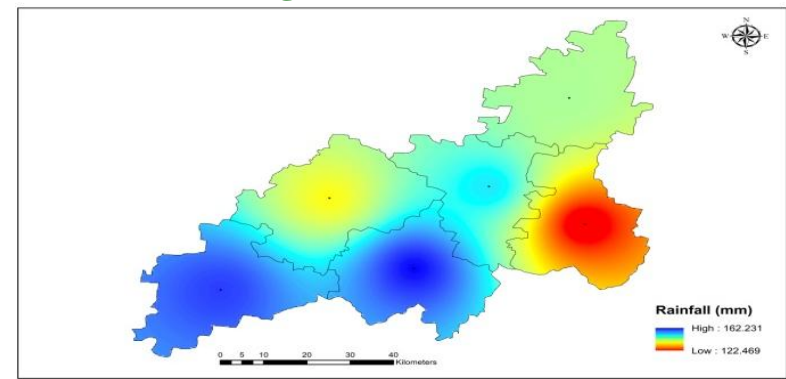

Fig.21 RGS (2015)

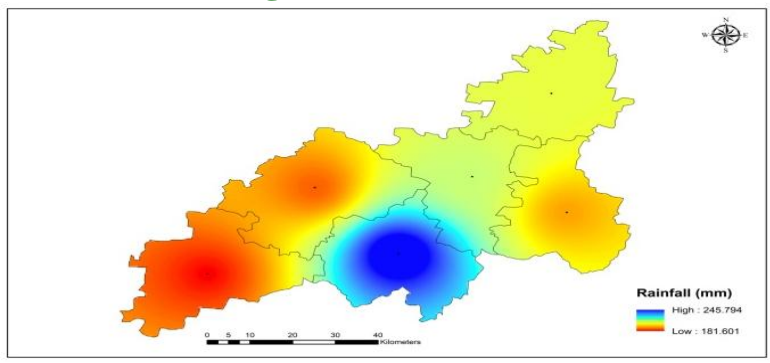

Fig.23 RGS (2016) 


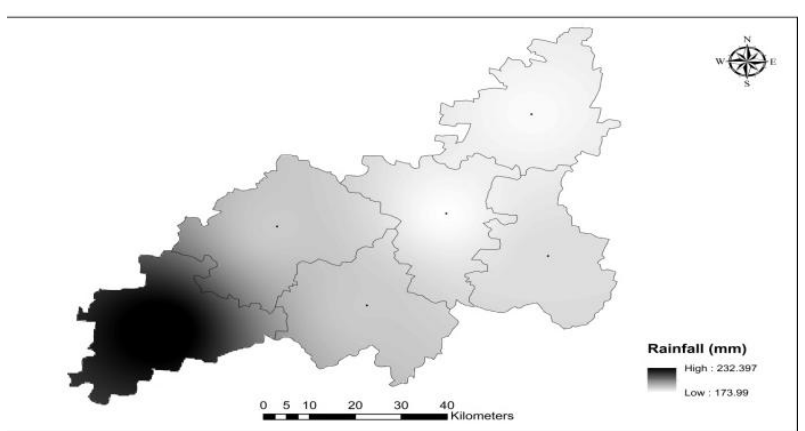

Fig.24 TRMM (2017)

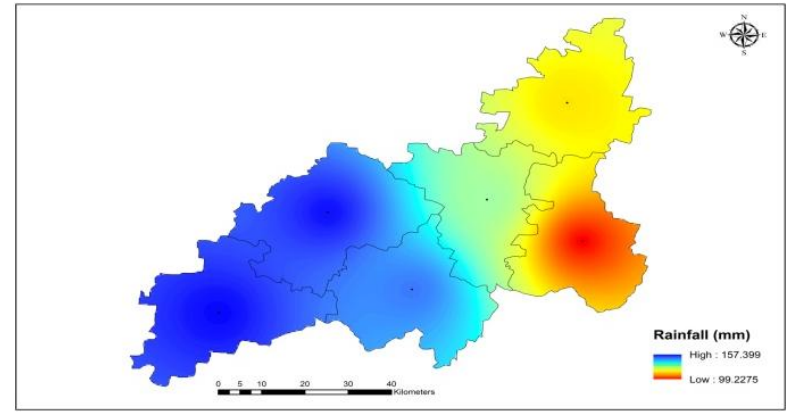

Fig.25 RGS (2017)

RGS: Rain Gauge Station, TRMM: Tropical Rainfall Measurement Mission

Therefore, it is evident from Table 3 that during rainy season very low agreement exists between TRMM based satellite data and gauge rainfall data.

To further evaluate the relationships between the two data sets, the scatter plots of seasonal TRMM rainfall against rain gauges rainfall data is shown in Fig. 3. The results indicate moderate strong positive linear relationship between the two rainfall datasets, which is supported by the correlation coefficient $(\mathrm{r}=$ 0.78 ) with the regression line slope 0.81 . Where, the value of $r^{2}=0.61$ says that $61 \%$ of the variation in traditional rain gauges can capture by the TRMM 3B43 satellite. It reveals that there is some dissimilarity in the spatial distribution between the rain gauge stations and TRMM rainfall data of Washim district which may due to lack of ground rain gauge stations at some remote areas or diversified topography of the district area. For that reason, to recognize the accurateness of spatial distribution of the TRMM rainfall data, the spatial distribution of seasonal rainfall for all the years have been compared (Fig. 4-25). The validity of TRMM data in the Washim region was compared with average monthly rainfall variations in monsoon season and almost similar variations were observed in both the data sets at all the subdistricts. But, still there are many difficulties in quantifying the precision of spatial rainfall distribution derived from the TRMM 3B43 rainfall data. Although the results (Fig. 4 - 25) show that TRMM rainfall data tend to overestimate rainfall. Sometime underestimated that may because of satellite like TRMM 3B43unable to detect the extreme rainfall in a precise manner. As the TRMM mission has ended in April 2015, in future it is essential to develop new algorithms of satellite based rainfall estimation, on the basis of better spacetime resolutions to overcome the deficiencies of single sensor methods (Michaelides et al., 2009). Since satellite based precipitation data is now widely used by hydrologists and engineers in various disciplines, new revolutionary data for more accurate results are essential.

This research is an attempt to evaluate satellite rainfall estimates of Tropical Rain Measurement Mission (TRMM 3B43) over rain gauges (Indian Meteorological Department) observations. Monthly accumulated rainfall collected by the rain gauge was compared with TRMM measurements for selected Washim district with six stations. Results suggest that TRMM rainfall measurements are highly overestimated, showing high baises. It is concluded from the analysis that there is some dissimilarity in the spatial distribution between the rain gauge stations and TRMM rainfall data of Washim district which may due to lack of ground rain gauge stations at some remote areas or diversified topography of the district area. Hence, it may be useful in estimating rainfall particularly in regions where no gauge observations available and therefore such measurements are useful for many water related applications. Results also indicated that rain is highly variable from one rainy season to another. 


\section{References}

Adler, R. F., Huffman, G. J. and Bolvin, D. T., Curtis, S., \& Nelkin E. J (2000). Tropical Rainfall Distributions Determined Using TRMM Combined with Other Satellite and Rain Gauge Information. Journal of Applied Meteorology (39), 2007-2023.

Huffman, G.J., Adler, R.F., Bolvin, D.T., Gu, G., Nelkin, E.J., Bowman, K.P., Hong, Y., Stocker, E.F. \& Wolff, D.B., (2007). The TRMM Multisatellite Precipitation Analysis (TMPA): quasi-global, multiyear, combined-sensor precipitation estimates at fine scales. Journal of Hydrometeorology8 (1), pp. 38-55.

Jamieson P, Porter J, Wilson D. A test of the computer simulation model ARCWHEAT1 on wheat crops grown in New Zealand. Field Crop Res. 1991; 27(4):337-50.

Kummerowa, C., Simpson, J., Thielea, O., Barnesa, W., Changa, A.T.C., \& Stockera, E (2000). The Status of the Tropical Rainfall Measuring Mission (TRMM) after Two Years in Orbit. Journal of Applied Meteorology, (39), 1965-1982.

Mitra, A. K., Bohra, A. K., Rajeevan, M. N., \& Krishnamurti, T. N (2008). Tropical Rainfall Distributions Determined Using TRMM Combined with Other Satellite and Rain Gauge Information. Journal of Meteorological Society of Japan, (87A), 265-279.

NASA. National Aeronautics and Space Administration. GPM Mission Concept, 2011. http://pmm.nasa.gov/gpm.

Nerini, D., Zulkafli,Z., Wang, L., Onof, C., Buytaert, W., \& Casimiro, W. L., \& Guyot, J. L. (2015). A Comparative Analysis of TRMM-Rain Gauge Data
Merging Techniques at the Daily Time Scale for Distributed Rainfall-Runoff Modeling Applications. Journal of Hydrometeorology, 16(5), 2153-2168.

Santos, A.S.P. Análise de desempenho dos campos de chuva estimados pelo satélite TRMM na Paraíba, para fins de modelagem hidrológica distribuída. 2014. 128 f. Dissertação (Mestrado em Engenharia Urbana e Ambiental) Universidade Federal da Paraíba, João Pessoa, 2014.

Shukla, A.K., Ojha, C.S.P. and Garg, R.D. (2014). Satellite based estimation and validation of monthly rainfall distribution over upper Ganga river basin. The International Archives of the Photogrammetry, Remote Sensing and Spatial Information Sciences, Volume XL-8, 2014. ISPRS Technical Commission VIII Symposium, December 9-12, 2014, Hyderabad, India, pp. 399404.

Signoretto M, Van de Plas R, De Moor B, Suykens J. Tensor versus matrix completion: a comparison with application to spectral data. IEEE Signal Process Letter. 2011; 18(7): 403-6.

Simpson J, Adler R, North G. A proposed tropical rainfall measuring mission (TRMM) satellite. Bull Am Meteorol Soc. 1988; 69(3): 278- 95.

Teng H. F., Ma Z., Chappell A., Shi Z., Liang Z and $\mathrm{Wu} \mathrm{Yu} \mathrm{(2017).} \mathrm{Improving} \mathrm{Rainfall}$ Erosivity Estimates Using Merged TRMM and Gauge Data. Remote Sensing (9) 1134, 1-15.

Willmott C, Matsuura K. Advantages of the mean absolute error (MAE) over the root mean square error (RMSE) in assessing average model performance. Climate Res. 2005; 30(1): 79-82.

\section{How to cite this article:}

Sudarshan Awatade, Sumedh R. Kashiwar, Souvik Ghosh, R.B. Singhandhupe, Usha R. Dongarwar and Digvijay S. Dhakre. 2018. Satellite Based Estimation and Validation of Rainfall Distribution in Monsoon over Washim (Maharashtra), India. Int.J.Curr.Microbiol.App.Sci. 7(08): 1694-1704. doi: https://doi.org/10.20546/ijcmas.2018.708.194 